\title{
Trichostasis Spinulosa of the Heel: Unique Presentation with Characteristic Morphology
}

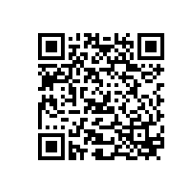

\author{
Mohamed Alhamar, Rand Abou Shaar Shereen Zia and Adrian Ormsby * \\ Department of Pathology and Lab Medicine, Henry Ford Health System, USA
}

Submission: May 13, 2020; Published: May 20, 2020

*Corresponding author: Adrian Ormsby, Department of Pathology and Lab Medicine, Henry Ford Health System, Detroit, USA

\begin{abstract}
Trichostasis Spinulosa is a peculiar lesion of the hair follicle that typically presents on the face. We present a case of a 59 years old MiddleEastern male who presented with a dark lesion on his heel. Examination revealed a $1.7 \mathrm{~cm}$ well-circumscribed black necrotic plaque with surrounding overhanging border with a differential diagnosis of melanoma. Histologically, the lesion was formed by inflamed clusters of numerous small hair shafts, consistent with Trichostasis Spinulosa of the heel. We report this case because of its unusual location and unique presentation.

Keywords: Trichostasis Spinulosa; Heel; Pigmented Lesion
\end{abstract}

\section{Introduction}

Trichostasis Spinulosa is a benign disorder of the hair follicle. It is formed by aggregates of numerous vellus hair in a dilated hair follicle [1]. The lesion was first described by Nobel in 1913 [2] and majority of cases presents clinically as black macules on the face, typically the nose [3].

\section{Case Report}

This lesion belonged to a 59 years old Middle-Eastern male, presented with a 1-week history of blister on his left foot which recently drained clear fluid leaving a black lesion at the base. He denied recent trauma or pain although sensation was altered due to his multiple sclerosis. Of note, the patient had a skin lesion on his back a year before his current presentation and was diagnosed as Trichostasis Spinulosa. On examination, the left heel showed a 1.7 $\mathrm{cm}$ well-circumscribed black necrotic plaque with surrounding overhanging border (Figure 1). The lesion did not improve with conservative treatment and an excisional biopsy was performed. Microscopically, the lesion showed a mixture of inflammation, ulceration and clusters of numerous small hair shafts/vellus hair, consistent with Trichostasis Spinulosa (Figures $2 \& 3$ ).

\section{Discussion}

Trichostasis Spinulosa is a common disorder of the pilosebaceous unit with unknown etiology [4]. Clinically, the lesion can be confused with talon noir, nodular melanoma, pigmented neuropathic ulcer and eccrine carcinoma while microscopically keratosis pilaris, comedogenic acne, eruptive vellus hair cysts, and Favre-Racou chot syndrome are the main differential diagnoses [5]. Various treatment regimens tried including hydroactive adhesive pads, retinoic acids, local keratolytics and laser but most of these showed inconsistent results [6]. In conclusion, Trichostasis Spinulosa can deviate from its usual clinical presentation of a black macule on the face and present at an unusual site that can also clinically mimic melanoma. Therefore, it is important to be aware of this entity.

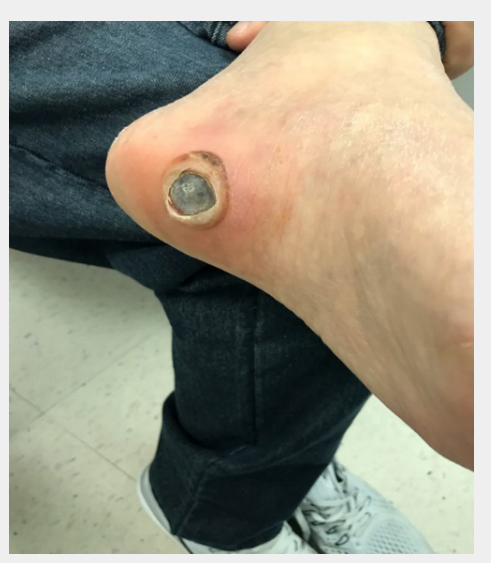

Figure 1: Left heel showing well-circumscribed black necrotic plaque with surrounding overhanging border, concerning for melanoma. 
Figure 2: Low power view of showing surface ulceration with numerous hair shafts.
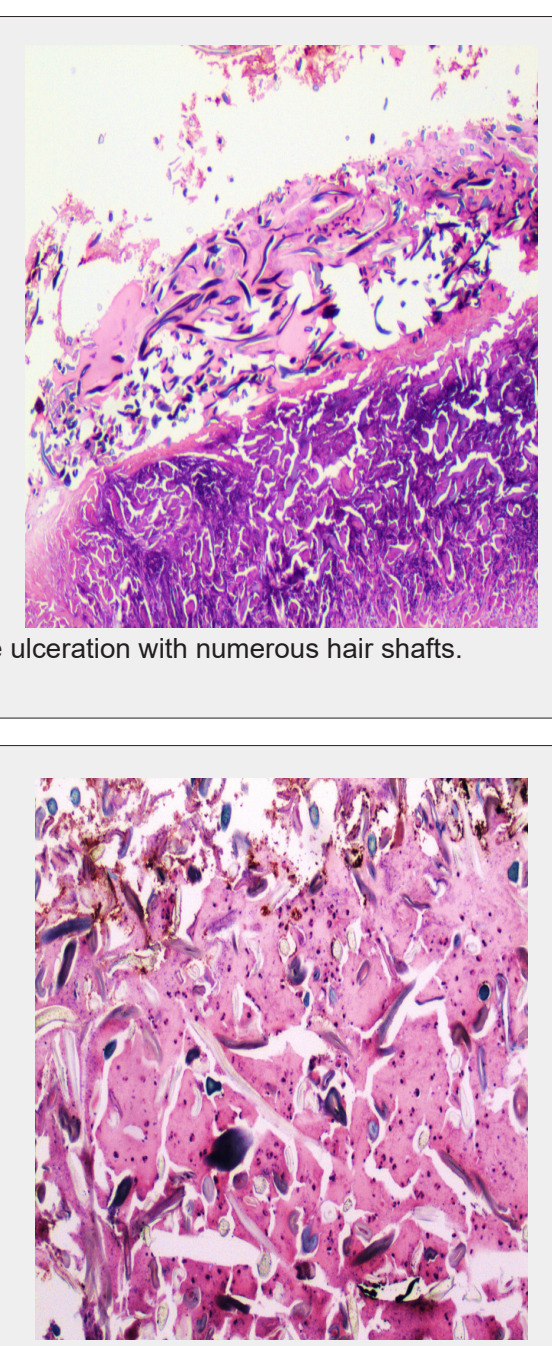

Figure 3: High power view showing numerous vellus hair with scattered acute inflammatory cells.

\section{References}

1. Chagas FS, Donati A, Soares II, Valente NS, Romiti R (2014) Trichostasis spinulosa of the scalp mimicking alopecia areata black dots. An Bras Dermatol 89(4): 685-687.

2. Nobl G (1913) Trichostasis spinulosa. Arch Dermatol Syph 114: 611.

3. White SW, Rodman OG (1982) Trichostasis spinulosa. J Natl Med Assoc 74(1): 31-33.
4. Gutte RM (2012) Itchy black hair bristles on back. Int J Trichology 4(4): 285-286.

5. Kundu A, Kundu T, Gon S (2016) Trichostasis Spinulosa: An Unusual Diagnosis Presenting as a Double Lower Eyelid. Int J Trichology 8(1): 21-33.

6. Ramteke MN, Bhide AA (2016) Trichostasis Spinulosa at an Unusual Site. Int J Trichology 8(2): 78-80.

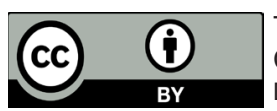

This work is licensed under Creative Commons Attribution 4.0 License DOI: $10.19080 / J O J D C .2020 .02 .555600$

\section{Your next submission with Juniper Publishers} will reach you the below assets

- Quality Editorial service

- Swift Peer Review

- Reprints availability

- E-prints Service

- Manuscript Podcast for convenient understanding

- Global attainment for your research

- Manuscript accessibility in different formats ( Pdf, E-pub, Full Text, Audio)

- Unceasing customer service

Track the below URL for one-step submission https://juniperpublishers.com/online-submission.php 